\title{
Capital Flows, Trade and the Role of the Financial System
}

\author{
Emmanuel Amissah \\ Nottingham Trent University, Nottingham, UK \\ Email: emmanuel.amissah@ntu.ac.uk
}

How to cite this paper: Amissah, E. (2018) Capital Flows, Trade and the Role of the Financial System. Modern Economy, 9, 1592-1617.

https://doi.org/10.4236/me.2018.99099

Received: September 4, 2018

Accepted: September 25, 2018

Published: September 28, 2018

Copyright $\odot 2018$ by author and Scientific Research Publishing Inc. This work is licensed under the Creative Commons Attribution International License (CC BY 4.0).

http://creativecommons.org/licenses/by/4.0/

\begin{abstract}
In this study, we examine the crucial role played by financial development in the relationship between trade and capital flows. We examine this relationship for 130 countries from 1980 to 2005 for different types of capital flows. We show that the relationship depends on the type of capital flows and the level of financial development. We observe a positive interaction between trade liberalisation and financial development for portfolio flows. In the case of FDI (Foreign Direct Investment), we observe an insignificant relationship. The FDI flows bypass the financial system as it flows into such countries because of other factors as side the level of the financial development.
\end{abstract}

\section{Keywords}

Financial Development, Trade Liberalisation, Capital Flows

\section{Introduction}

The important role of financial development in influencing the patterns of capital flows cannot be over emphasised within the current world economic system. A higher level of financial development promotes production and exports especially from financially dependent sectors [1] [2].

However, such observations have been made without considering the influential role of financial integration. While financial development will create the right institutional environment to support productivity, opening the economy by removing restrictions for foreign participation was important to fully enjoy the benefits of financial development. This is because most research has either focused on trade specific relationship or international finance. However, current studies have shown that this distinction between trade and financial integration is not warranted [3] [4] [5] [6] [7]. This new literature has explored new channels. Ju and Wei [8] showed that capital flows in the form of FDI can substitute 
for the financial system as they lead to a complete by-pass of the financial system. Capital flows can alleviate the problems that financial constrained firms face domestically, especially, in economies with poorly developed financial systems by providing these firms with access to capital and know how through joint ventures and spill-over effects [7] [9]. This could lead to an increase in exports as FDI combines with domestic labour to enhance domestic efficiency and thus boost production and exports. However, this form of capital flow may contribute less to the domestic financial systems as it can by-passes them by utilizing foreign capital.

Contrarily, capital flows in the form of financial capital ${ }^{1}$ according to the Lucas paradox and Heckscher-Ohlin-Mundell model can lead to capital and trade substitutability. Financial capital moves from developing countries to developed countries because of the high nature of the agency problems, poor corporate governance, high intermediation costs, poor contractual enforcement, high cost of physical capital, consistent government defaults and the poor state of the balance sheet of the business sector in developing economies compared to developed economies [7]-[12]. So even though one should expect that allowing for capital flows should bring in capital to support financially constrained firms in capital deprived developing countries, in reality this might not be the case.

The preceding arguments show clearly that it is important to consider the type of capital flow (FDI versus portfolio) when we analyse the role of capital flows in the economy. Taking an aggregate look at capital flows can mask a lot of important details that a disaggregated examination can show. When capital flows take the form of FDI, they can lead to a much more positive impact especially in the areas of productivity gains through spillover effects and exports ${ }^{2}$ despite the possible by-pass of the financial systems whilst capital flows in the form of financial capital (portfolio flows) can sometimes to lead to capital flight due to the poor financial development. Nevertheless, trade and capital flows in the presence of financial development can complement each other and not necessarily be substitutes [4].

In this study, we provide an empirical investigation of the relationship between trade and capital flows in a panel setting ${ }^{3}$. The objective of this study is to determine the impact of trade liberalisation on capital flows taking into account the level of financial development. We also look at how this relationship varies between the different types of capital flows.

Recently, a number of papers have examined different aspects of the relationship between capital flows and international trade. Our study relates to different strands of the literature. Firstly, it contributes to the literature on FDI and its relationship with the level of financial development. Manova et al. [7] showed that FDI can alleviate the problems that domestic financial market creates with re-

${ }^{1}$ See Caves (1996) for a detailed theoretical and empirical examination of FDI.

${ }^{2}$ See Caves [13] for a detailed theoretical and empirical examination of FDI.

${ }^{3}$ Apart from Aizenman and Noy [16], most of the work related to our study has been done under a cross country framework. 
spect to hindering trade and influencing patterns of trade. A similar result was obtained by Antras et al. [14]. They show the interrelationship between FDI flows and the activities of Multinational Corporations (MNC). We extend the work done in these papers by looking at a cross country study for different types of capital flows. However, Alfaro et al. [9] showed that FDI's impact on growth is ambiguous in the absence of a properly functioning financial institution. Is this the case as well when we consider trade and FDI?

Most papers have studied how important the financial system is to a country that desires to harness the positive impact of capital flows especially FDI. Alfaro et al. [9] in a simple theoretical model and empirical analysis showed how the positive contribution of FDI on economic growth depended on the effective functioning of the financial system. Similarly, Tornelle et al. [15] studied the effect of financial liberalisation on growth through a thorough examination of the link among trade liberalisation, financial fragility and growth across countries. They observed that liberalisation episodes did not only coincide with economic booms but also periods of economic recession. However, they identified that for developing countries, trade liberalisation was followed by financial liberalisation. This is because such countries required finance to support trade expenses.

This paper also contributes to the literature on trade and capital account sequencing. Chinn and Ito [17] examined the issue of sequencing by investigating whether opening trade was a pre-condition for financial liberalisation. Using the Chinn-Ito capital account index as the dependent variable they examined the impact of trade openness on current capital account openness. They obtained a positive relationship between financial openness and trade openness. This means that openness in goods transactions is a precondition for financial openness. Again, they identified that the capital account index does clearly distinguish between financial capital and FDI. The role of financial developments in this relationship was not considered which we do in our paper. As an additional contribution in the above study, Aizenman and Noy [16] also investigated the relationship between trade and capital at a much disaggregated level. They focus on capital flows in the form of FDI and studied how these disaggregated trade influenced the level of FDI. They obtained a significantly positive relationship for developing and developed countries in the case of total trade, goods and income but no significant relationship in the case of services. Once again, we add to this study by looking at the role of financial development in this relationship directly and investigate capital flows under the different types of capital flow. This overcomes the concerns raised by Chinn and Ito [17] as we separate financial capital from FDI in our study.

On the literature of capital flows and financial development, Klein and Olivei [18] showed that the capital account opening has a significant impact on financial depth. Once again, these were done in a cross sectional style averaging samples from 1986 to 1995 and 1976 to 1995. Earlier papers have examined a similar question analysing the effect of capital opening on financial depth [19] [20]. 
The rest of the papers is organised as follows: Section 2 introduces the methodological approach employed whiles Section 3 shows a description of the data employed. In Section 4 we provide the results and Section 5 addresses issues of endogeneity. The paper is concluded in Section 6.

\section{Methodology}

In this study, we attempt to throw more light on trade and capital flow relationship by appraising the salient role of financial development and a disaggregation of capital flows. As a unique contribution in this area of research, we account for these concerns in our econometric estimation to provide an empirical contribution to trade and capital flow relationship. Using a fixed effect approach, we test the effect of trade liberalisation on the different indicators of capital flows in the presence of the country's level of financial development. Specifically, we interact each country's level of financial development with trade liberalisation. The model is estimated as follows:

$$
\begin{aligned}
\mathrm{CF}_{c t}= & \alpha_{0}+\beta_{0} \mathrm{TLIB}_{c t}+\beta_{1}\left(\mathrm{TLIB}_{c t} \times \mathrm{FINDEV}_{c t}\right) \\
& +\beta_{2} \mathrm{FINDEV}_{c t}+\beta_{3} \mathrm{CTL}_{c t}+\gamma_{t}+\gamma_{c}+\varepsilon_{c t}
\end{aligned}
$$

where dependent variable, $\mathrm{CF}_{c t}$, is a measure of capital flows for each country $c$ in year $t$. We use FDI, portfolio flows, portfolio plus bonds flows, Chinn-Ito index of capital openness to represent capital flows. TLIB $_{c t}$ is a trade liberalisation binary variable for each country $c$ in year $t$. This variable takes the value of 1 after the country opens for trade and 0 when they are remain closed. FINDEV is a measure of the level of financial development for country $c$ in year $t . \mathrm{CTL}_{c t}$ is set of control variables for each country $c$ in year $t$. It contains macroeconomics and institutional control variables. $\gamma_{t}$ and $\gamma_{c}$ are the time and country specific effects respectively. $\gamma_{t}$ is included to capture any time varying omitted variables and $\gamma_{c}$ account for country specific omitted characteristics. The coefficient of interest $\beta_{1}$ is identified through an intricate process of interaction between these two country level variables over time. The expected sign on $\beta_{1}$ will depend on the type of capital flows that is considered.

\section{Data and Descriptive Statistics}

We measure the level of financial development using the indicators from Beck, et al. [21]. We use three different indicators for the level of financial development. One of the key country level indicators used to measure the level of financial development is the private credit by deposit money banks to GDP variable. This measures credit obtained by private sector from financial intermediaries. This measure is employed because it captures the level of activity in the financial system, especially, the lending capacity of the financial sector. This variable, therefore, tells us something about the use of funds and not just its availability. This variable is computed with credit provided by deposit money banks. The second variable used to measure the level of financial development is similar to the above but its computation has a wider coverage. It is computed with credit 
provided by both deposit money banks as well as other financial institution. We use both measures because the latter measure provides a much more inclusive data given the growing services provided by non-bank institution, whilst the former is broader measure on the availability for more countries. For sensitivity analysis and robustness, we use other measures of financial development. To capture the size and activity of market especially in the mobilisation and allocation of funds in the financial system, we use stock market capitalisation to GDP. This is used as the third measure of the level of financial development ${ }^{4}$.

For the dependent variable, we use four different indicators to capture capital flows. A disaggregated measure of capital flows is more appropriate as each specific flow type is unique, especially, in terms of taxes with respect to the efficiency in tax collection and different degree of expropriation of risk [5]. We use portfolio flows to capture the level of financial capital as a form of capital flows. This data is sourced from World Bank's World Development Indicators (WDI). It includes net inflows from equity securities, but excludes any item recorded as direct investment. Equity securities included are shares, stocks, depository and direct purchase of shares in a local market by foreign investors. Because this indicator of capital flows did not include bonds, we created a similar indicator of portfolio flows but added bonds. Once again, we use both indicators because in the case of the portfolio flows plus bond, we lose some observation as it is not available for some countries and available for a few years for some countries. However, it offers a more inclusive indicator of financial capital. We also use FDI as another capital flow indicator. We source this data from WDI. This indicator is the net inflows of investment to acquire a lasting management interest of $10 \%$ or more of voting stock in an enterprise [22]. This investment must be done by people of nationals other than the investing country. It includes equity capital, reinvestment of earnings, other long term capital and short term capital which they obtain from the balance of payment of the reporting country. To measure the aggregate level of overall capital flow, we use Chinn-Ito index developed by Chinn and Ito [19]. We use this indicator to observe if our separate indicator of capital flows (FDI and Financial capital) were different from this aggregate indicator in terms of the impact of trade openness in the presence of financial development. This measure captures the extent and the intensity of openness in the capital account. This is an indicator computed through a principal component analysis from the binary indicators of the Annual Report on Exchange Arrangement and Exchange Restrictions (AREAER) from the International Monetary Fund (IMF). The variables are computed based on four categories prior to $1996^{5}$ : current account restrictions, capital account restrictions, the existence of multiple exchange rates, the requirement of surrender of export proceed (Chinn et al., 2006) ${ }^{6}$.

${ }^{4}$ All three measures of the level of financial development are indicators used widely in the financial development literature [23].

${ }^{5}$ For the purposes of providing much detail, the IMF extended the binary classification from 4 to 13 . ${ }^{6}$ Chinn and Ito extended the four category reporting style of the AEARER by following Mody et al. [24]. 
Data covers 130 countries. Out of which 101 are developing countries (low and middle income countries) and 29 are developed countries (High income countries). It covers 38 countries from Europe and central Asia, 10 from East Asia and Pacific, 25 from Latin America and Caribbean, 40 from Sub-Saharan African countries, 6 from South Asia, and 11 from Middle East and North America.

Table 1 presents the averages for all the capital flows variables for the entire sample and sub-samples. We observe a high average for the high income countries when we consider portfolio flows compared to the developing countries. However, a lower average is observed for the high income OECD countries for the case of FDI flows. An opposite trend is shown when we look at developing countries. Low and middle income countries have a much higher net flows for FDI compared to net portfolio flows.

For trade openness indicator, we use the dataset by Warcziarg and Welch [25] hereafter WW. The advantage with these data is that they provide an extension to the very popular Sachs and Warner [26] (hereafter SW) trade openness data. WW updated these data by providing trade liberalisation information for more countries as well as providing an update for a few of the existing trade liberalisation dates in SW's data. They both compute the date using two approaches. Firstly, this indicator is computed using criteria based on the following 5 characteristics: "Average tariff rates of $40 \%$ or more, non tariff barriers covering $40 \%$ or more of trade, a black market exchange rate depreciated by $20 \%$ or more relative to the exchange rate, a state monopoly on major export, and a socialist economic system" [25]. Most of the liberalisation dates were computed using the above approach. However, on a few special cases where the criteria information could not be found, survey studies of liberalisation for those countries was used. Because our sample extends through to 2005, we extend the data on trade liberalisation for five more years.

We use World Trade Organisation (WTO) information on trade liberalisation periods to verify if those countries that remain closed at the end of the WW's sample (1999) were still closed or open ${ }^{7}$. This trade liberalisation variable is an openness dummy which turns one when the countries opened for trade and 0

Table 1. Averages for capital flow types for the various income group ${ }^{8}$.

\begin{tabular}{|c|c|c|c|c|c|}
\hline Variable & $\begin{array}{l}\text { Whole } \\
\text { sample }\end{array}$ & Low Income & $\begin{array}{l}\text { Middle } \\
\text { Income }\end{array}$ & $\begin{array}{l}\text { High Income: } \\
\text { non OECD }\end{array}$ & $\begin{array}{c}\text { High Income: } \\
\text { OECD }\end{array}$ \\
\hline Chinn-Ito index & 0.108 & -0.795 & -0.082 & 0.81 & 1.592 \\
\hline Portfolio flows 1 & 1.151 & 0.71 & 0.214 & 2.190 & 0.838 \\
\hline Portfolio flows 2 & 1.253 & 0.851 & 0.465 & 2.098 & 0.792 \\
\hline FDI flows & 2.065 & 1.245 & 2.431 & 3.682 & 1.903 \\
\hline
\end{tabular}

Where Portfolio flow 1 is equity flows only and Portfolio flows 2 is equity and bond flows.

${ }^{7}$ The other option of countries that were open for trade going back to close trade is highly unlikely. ${ }^{8}$ Income group classification was based on World Bank's income and regional classification system. 
otherwise. The data on trade liberalisation are available for 130 countries between 1980 and 2005. In this period, 80 liberalised trade, 37 opened for trade prior to 1980 and 13 remain closed at the end of 2005 .

For a first glance at the data, we look at the Bravais-Pearson correlation coefficient between the trade liberalisation dummy and the various indicators of capital flow for the whole sample and the different income groups.

For Table 2, we observe a significant positive correlation amongst all the capital flow types and trade liberalisation. We also notice that FDI has a larger positive correlation with trade liberalisation compared to portfolio flows.

For the sub sample correlations of the different income groups, we notice significant positive relationship between net FDI inflows and trade liberalisation for the low and the middle income groups and an insignificant correlation between FDI flows and trade liberalisation for the high income countries (Tables 3-5).

However, for portfolio flows, we observed that the high income (non-OECD) group had the highest positive correlation between portfolio flows 1 and 2with trade liberalisation (Table 6). For the Chinn-Ito index, developing countries had a much lower association between the index and portfolio flows but a significant relationship with FDI. A look at the high income group shows the opposite. Whilst there is a significant positive relationship between portfolio flows and the Chinn-Ito index, there is an insignificant relation between FDI flows and Chinn-Ito index.

Alternatively, we examine the flow of capital for portfolio and FDI around the

Table 2. Correlation of capital flows and trade liberalisation (Whole Sample).

\begin{tabular}{cccccc}
\hline Correlation & $\begin{array}{c}\text { Chinn-Ito } \\
\text { index }\end{array}$ & $\begin{array}{c}\text { Portfolio flows } \\
1\end{array}$ & $\begin{array}{c}\text { Portfolio } \\
\text { flows 2 }\end{array}$ & FDI flows $\begin{array}{c}\text { Trade } \\
\text { liberalisation }\end{array}$ \\
\hline Chinn-Ito index & 1 & & & \\
Portfolio flows 1 & $0.2250^{*}$ & 1 & & \\
Portfolio flows 2 & $0.2257^{*}$ & $0.9976^{*}$ & 1 & 1 & \\
FDI flows & $0.2302^{*}$ & $0.0603^{*}$ & $0.0615^{*}$ & 1 & \\
Trade liberalisation & $0.3568^{*}$ & $0.1197^{*}$ & $0.1256^{*}$ & $0.1533^{*}$ & 1 \\
\hline
\end{tabular}

Asterisks indicate 5 percent level of significance.

Table 3. Correlation of capital flows and trade liberalisation (Low Income Sample).

\begin{tabular}{|c|c|c|c|c|c|}
\hline Correlation & $\begin{array}{l}\text { Chinn-Ito } \\
\text { index }\end{array}$ & $\begin{array}{c}\text { Portfolio flows } \\
1\end{array}$ & $\begin{array}{l}\text { Portfolio } \\
\text { flows } 2\end{array}$ & FDI flows & $\begin{array}{c}\text { Trade } \\
\text { liberalisation }\end{array}$ \\
\hline Chinn-Ito index & 1 & & & & \\
\hline Portfolio flows 1 & -0.0359 & 1 & & & \\
\hline Portfolio flows 2 & -0.041 & $0.8756^{*}$ & 1 & & \\
\hline FDI flows & $0.3010^{*}$ & -0.0167 & -0.0212 & 1 & \\
\hline Trade liberalisation & $0.1175^{*}$ & $0.1129^{*}$ & $0.1294^{*}$ & $0.1307^{\star}$ & 1 \\
\hline
\end{tabular}

Asterisks indicate 5 percent level of significance. 
Table 4. Correlation of capital flows and trade liberalisation (Middle Income Sample).

\begin{tabular}{cccccc}
\hline Correlation & $\begin{array}{c}\text { Chinn-Ito } \\
\text { index }\end{array}$ & $\begin{array}{c}\text { Portfolio flows } \\
\mathbf{1}\end{array}$ & $\begin{array}{c}\text { Portfolio } \\
\text { flows 2 }\end{array}$ & FDI flows & $\begin{array}{c}\text { Trade } \\
\text { liberalisation }\end{array}$ \\
\hline Chinn-Ito index & 1 & & & & \\
Portfolio flows 1 & $-0.0576^{*}$ & 1 & & & \\
Portfolio flows 2 & 0.0009 & $0.8550^{*}$ & 1 & & \\
FDI flows & $0.2382^{*}$ & -0.0229 & -0.0125 & 1 & \\
Trade liberalisation & $0.2767^{*}$ & $0.0605^{*}$ & $0.1208^{*}$ & $0.1949^{*}$ & 1 \\
\hline
\end{tabular}

Asterisks indicate 5 percent level of significance.

Table 5. Correlation of capital flows and trade liberalisation (High Income: Non OECD Sample).

\begin{tabular}{cccccc}
\hline Correlation & $\begin{array}{c}\text { Chinn-Ito } \\
\text { index }\end{array}$ & $\begin{array}{c}\text { Portfolio flows } \\
1\end{array}$ & $\begin{array}{c}\text { Portfolio } \\
\text { flows 2 }\end{array}$ & FDI flows & $\begin{array}{c}\text { Trade } \\
\text { liberalisation }\end{array}$ \\
\hline Chinn-Ito index & 1 & & & \\
Portfolio flows 1 & $0.1794^{*}$ & 1 & & \\
Portfolio flows 2 & $0.1794^{*}$ & $1.0000^{*}$ & 1 & 1 & \\
FDI flows & 0.1297 & $0.2422^{*}$ & $0.2422^{*}$ & 1 & 1 \\
Trade liberalisation & 0.1421 & $0.1920^{*}$ & $0.1920^{*}$ & 0.1498 & 1 \\
\hline
\end{tabular}

Asterisks indicate 5 percent level of significance.

Table 6. Correlation of capital flows and trade liberalisation (High Income: OECD Sample).

\begin{tabular}{cccccc}
\hline Correlation & $\begin{array}{c}\text { Chinn-Ito } \\
\text { index }\end{array}$ & $\begin{array}{c}\text { Portfolio flows } \\
1\end{array}$ & $\begin{array}{c}\text { Portfolio } \\
\text { flows 2 }\end{array}$ & FDI flows $\begin{array}{c}\text { Trade } \\
\text { liberalisation }\end{array}$ \\
\hline Chinn-Ito index & 1 & & & \\
Portfolio flows 1 & $0.2357^{*}$ & 1 & & \\
Portfolio flows 2 & $0.2357^{*}$ & $0.9321^{*}$ & 1 & 1 & \\
FDI flows & $0.2322^{*}$ & $0.1570^{*}$ & $0.1570^{*}$ & 1 & 1 \\
Trade liberalisation & $0.0994^{*}$ & 0.0385 & 0.0385 & 0.0316 & \\
\hline
\end{tabular}

Asterisks indicate 5 percent level of significance.

liberalisation dates graphically. We use countries which liberalise during the sample period ${ }^{9}$. In Figure 1, vertical lines represent the years of liberalisation for each country respectively. As the graph shows, most of the countries seem to have increased in capital flows after the liberalisation date despite the high volatility especially for portfolio flows. For more detailed support, we provide the pre and post liberalisation average analysis. The horizontal line in the figure captures the average for portfolio and FDI flow in the respective countries for the pre and post liberalisation periods.

${ }^{9} \mathrm{High}$ income countries were not used for the graphical analysis because most of them liberalised before the beginning of the sample except Israel. We select countries with liberalisation date that is closer to the middle of the sample in the exception of Israel so that we can have enough variation for pre and post liberalisation periods. 

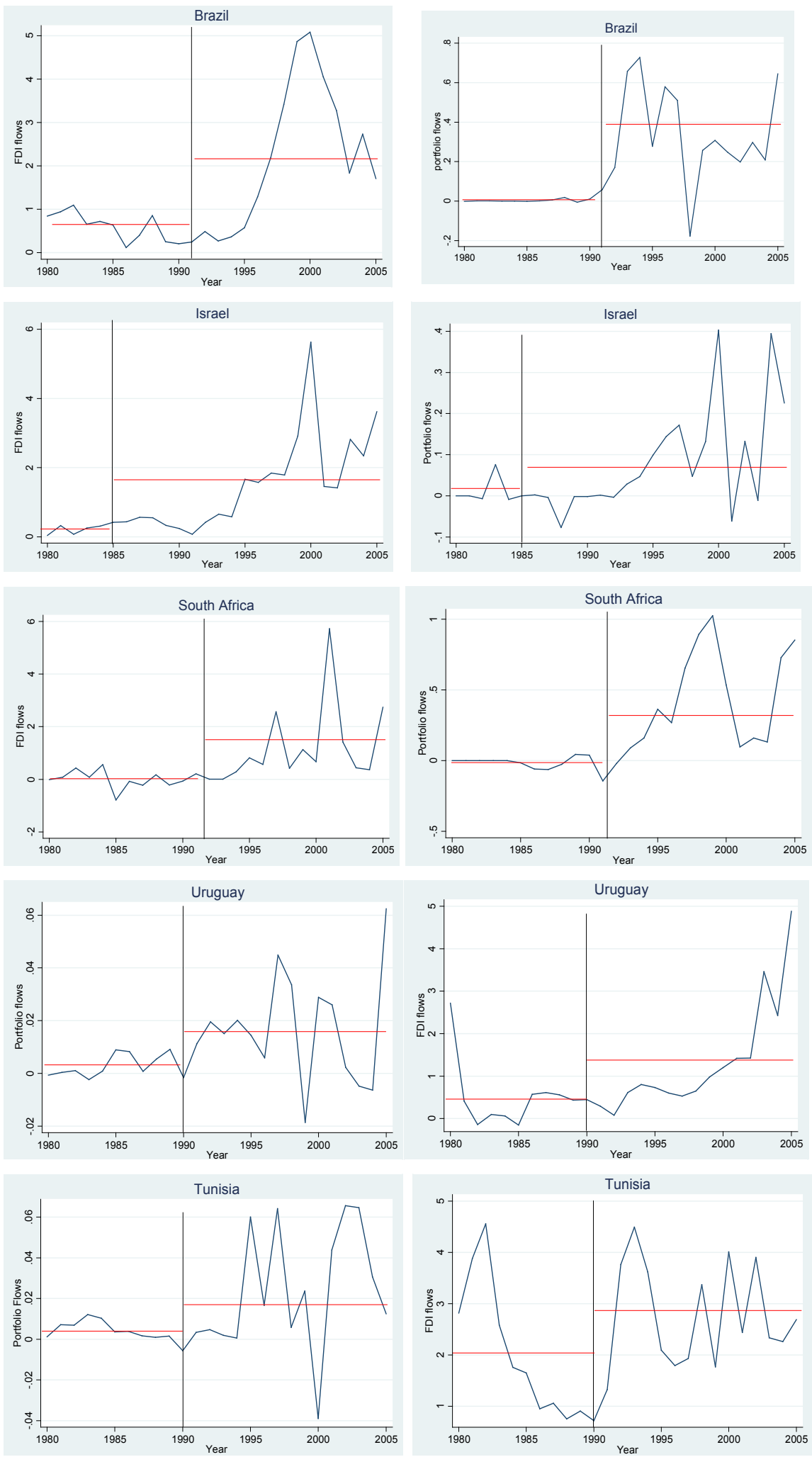

Figure 1. Capital flows and liberalisation.

We notice that in the case of portfolio flows, after liberalisation, averages are high across the countries chosen. Portfolio flows for almost all countries showed 
positive jumps after the liberalisation and stay above the pre-liberalisation level on average. However, Israel kept similar level after the liberalisation date for portfolio flows but showed increases later on in the after liberalisation period. In the case of FDI flows, almost all countries showed consistent increases immediately after liberalisation. There were much bigger and consistent increases after liberalisation. Overall, we could suggest that liberalisation partly impacted how capital flows have turned out even though it could be due to other likely reforms occurring during the same time and considering the fact that we also have not controlled for time trend.

We included a host of other variables as has been used in this area of research and more importantly to control for missing variable bias. In most of the regressions, we include gross domestic product, interest rate, and inflation rate (CPI), which are the major determinants of capital flow in standard models ${ }^{10}$ of capital flow. These data were taken from WDI and International Financial statistics of International Monetary Fund (IMF). A paper by Zingales and Rajan [27] showed the vital role of political economy's influences in cross border capital flows and trade. Similar variables are included in the paper by Antras et al. [5]. We, therefore, include two institutional variables to control for political economy influence.

We use a variable that measures the level of democratic rule from La Porta et al. [29]. This is an index of rule of law that assesses the law and order tradition of a country. Secondly, we use an index for corruption which captures the level of corruption within the government of that country. This index is also taken from La Porta et al. [29]. Both indices are scaled from 0 to 6 where 0 indicates high level of corruption for the case of the corruption index and poor law and order for the case of the rule of law index and 6 indicates the vice versa.

\section{Empirical Analysis}

In this section, we present the regression results for our baseline equation above and other robustness estimations. In Table 7, we present the results from the estimation for 103 countries from 1980 to 2005 for all four types of capital flow. In this results table, we show the relationship between capital flows and trade in the absence of controls for the level of financial development.

In Table 7, we show the results of the regression without controls with the exception of gross domestic product. From column 2 and 3, we notice an inverse relationship between capital flows and trade liberalisation when capital flows is identified by equity flows. A relationship that is significant at $1 \%$ level indicating substitutability in the relationship between capital flows and trade. But in the case of column 1 and 4, we observe a positive relationship when capital flows is identified by FDI inflow and the Chinn-Ito index. A similar result is obtained by Aizenman and Noy [5] when they study the impact of disaggregated trade on FDI openness index. In the case of the Chinn-Ito index, the result is supported ${ }^{10}$ The fundamental models include flow, stock and monetary approach with interest rate, wealth, and price level as the determinants [28]. 
Table 7. Capital flows and trade: the whole sample.

\begin{tabular}{ccccc}
\hline DEP VARIABLES & Chinn-Ito index & Portfolio flows 1 & Portfolio flows 2 & FDI flows \\
\hline TLIB & $0.222^{* * *}$ & $-0.195^{* * *}$ & $-0.178^{* * *}$ & 0.214 \\
& $(0.066)$ & $(0.045)$ & $(0.046)$ & $(0.180)$ \\
lgdp & $0.002^{* * *}$ & $0.020^{* * *}$ & $0.020^{* * *}$ & $0.004^{* * *}$ \\
& $(0.000)$ & $(0.003)$ & $(0.003)$ & $(0.001)$ \\
Observations & 2593 & Controls: country, year fixed effects & \\
Adjusted R-squared & 0.764 & 2713 & 2713 & 2579 \\
\hline
\end{tabular}

Robust standard errors in parentheses. ${ }^{* * *} \mathrm{p}<0.01,{ }^{* *} \mathrm{p}<0.05,{ }^{*} \mathrm{p}<0.1^{11}$.

by the work of Chinn and Ito [17] when they studied the sequencing between capital account and trade. Since the theoretical arguments have been based on developing countries, we estimate the above again for developed and developing countries in our sample $\mathrm{e}^{12}$.

From Table 8, we observe a positive and larger economic significance in the case of FDI and the Chin-Ito index. As argued by Antras and Caballero [5], there is higher reward for physical capital in developing countries because of scarcity of such resources. Hence FDI flows more into developing countries than it flows out from such countries. A much lower coefficient size compared to the FDI flows. More likely, as explain, when such countries open their borders; the tendency for capital to flow out is higher than for capital to flow in ${ }^{13}$. For the case of developed countries, in Table 9, we observe that there is a significant negative relationship between FDI flows and opening up for trade. Portfolio flows come out insignificant and negative. However, on the whole, we observe the general indicator of capital flows posit a positive influence of trade liberalisation on capital flows as indicated by the Chinn-Ito index in all three estimations above.

Furthermore, we consider as our main contribution what role the level of financial development will play in the relationship between the capital flow types and trade liberalisation. We use the three different indicators of financial development identified as FINDEV1, FINDEV2 and FINDEV $3^{14}$. From Table 10, we observe that the interaction between the level of financial development and trade liberalisation is positive and statistically significant at less than 10 percent. Economic significance of all the three interaction term is greater in size. The other constituent term, financial development, had negative sign and significant on few cases. However, given that the size of the coefficient on the interaction terms were consistently greater than constituent terms in all cases, the overall effect on portfolio capital flow is positive.

${ }^{11}$ All standard errors are clustered at the country level.

${ }^{12}$ The high Income countries form a small percentage of the whole sample. We reproduce most of the baseline results for developing countries only. See Appendix for these.

${ }^{13}$ See Kose et al. [30], Forbes [31] for similar results.

${ }^{14} \mathrm{FINDEV} 1$ is private credit to GDP from only banks, FINDEV2 is private credit to GDP from all financial institution, and FINDEV 3 is stock market capitalisation. 
Table 8. Capital flows and trade: developing countries.

\begin{tabular}{|c|c|c|c|c|}
\hline DEP VARIABLES & Chinn-Ito index & Portfolio flows 1 & Portfolio flows 2 & FDI flows \\
\hline \multirow[t]{2}{*}{ TLIB } & $0.490^{\star * *}$ & $0.014^{* *}$ & $0.030^{* * *}$ & $0.407^{* *}$ \\
\hline & $(0.070)$ & $(0.006)$ & $(0.008)$ & $(0.193)$ \\
\hline \multirow[t]{3}{*}{ GDP } & $0.004^{* *}$ & $0.008^{\star * *}$ & $0.011^{\star * *}$ & 0.004 \\
\hline & $(0.002)$ & $(0.002)$ & $(0.002)$ & $(0.005)$ \\
\hline & \multicolumn{4}{|c|}{ Controls: country, year fixed effects } \\
\hline Observations & 2055 & 2158 & 2158 & 2059 \\
\hline Adjusted R-squared & 0.704 & 0.437 & 0.448 & 0.498 \\
\hline
\end{tabular}

Robust standard errors in parentheses. ${ }^{* *} \mathrm{p}<0.01,{ }^{* *} \mathrm{p}<0.05,{ }^{*} \mathrm{p}<0.1$.

Table 9. Capital flows and trade: developed countries.

\begin{tabular}{ccccc}
\hline DEP VARIABLES & Chinn-Ito index & Portfolio flows 1 & Portfolio flows 2 & FDI flows \\
\hline TLIB & $0.810^{\star * *}$ & -0.423 & -0.423 & $-1.067^{\star * *}$ \\
GDP & $(0.165)$ & $(0.270)$ & $(0.270)$ & $(0.311)$ \\
& $-0.005^{\star * *}$ & $0.018^{\star * *}$ & $0.018^{\star * *}$ & $-0.006^{\star *}$ \\
Observations & $(0.002)$ & $(0.003)$ & $(0.003)$ & $(0.002)$ \\
Adjusted R-squared & 538 & 555 & 555 & 520 \\
\hline
\end{tabular}

Robust standard errors in parentheses. ${ }^{* *} \mathrm{p}<0.01,{ }^{* *} \mathrm{p}<0.05,{ }^{*} \mathrm{p}<0.1$.

Table 10. Capital flows and trade for the whole sample: baseline regression.

\begin{tabular}{|c|c|c|c|c|c|c|}
\hline VARIABLES & $\begin{array}{c}\text { Portfolio } \\
\text { flows } 2\end{array}$ & $\begin{array}{l}\text { Portfolio } \\
\text { flows } 2\end{array}$ & $\begin{array}{c}\text { Portfolio } \\
\text { flows } 2\end{array}$ & $\begin{array}{l}\text { Portfolio } \\
\text { flows } 1\end{array}$ & $\begin{array}{l}\text { Portfolio } \\
\text { flows } 1\end{array}$ & $\begin{array}{c}\text { Portfolio } \\
\text { flows } 1\end{array}$ \\
\hline \multirow[t]{2}{*}{ FINDEV1 } & $-0.321^{\star}$ & & & $-0.315^{\star}$ & & \\
\hline & $(0.165)$ & & & $(0.164)$ & & \\
\hline \multirow[t]{2}{*}{ FINDEV $1 \times$ TLIB } & $0.567^{* * *}$ & & & $0.551^{* * *}$ & & \\
\hline & $(0.136)$ & & & $(0.135)$ & & \\
\hline \multirow[t]{2}{*}{ FINDEV2 } & & 0.028 & & & 0.022 & \\
\hline & & $(0.216)$ & & & $(0.215)$ & \\
\hline \multirow[t]{2}{*}{ FINDEV $2 \times$ TLIB } & & $0.256^{\star *}$ & & & $0.233^{\star *}$ & \\
\hline & & $(0.117)$ & & & $(0.116)$ & \\
\hline \multirow[t]{2}{*}{ FINDEV3 } & & & -0.210 & & & -0.257 \\
\hline & & & $(0.356)$ & & & $(0.361)$ \\
\hline \multirow[t]{2}{*}{ FINDEV $3 \times$ TLIB } & & & $0.596^{*}$ & & & $0.631^{\star}$ \\
\hline & & & $(0.322)$ & & & $(0.328)$ \\
\hline \multirow[t]{2}{*}{ TLIB } & $-0.220^{* * *}$ & $-0.224^{\star * *}$ & -0.038 & $-0.234^{* * *}$ & $-0.236^{* * *}$ & $-0.112^{\star *}$ \\
\hline & $(0.053)$ & $(0.053)$ & $(0.058)$ & $(0.052)$ & $(0.053)$ & $(0.056)$ \\
\hline \multirow[t]{2}{*}{ GDP } & $0.020^{\star * *}$ & $0.020^{\star * *}$ & $0.027^{\star * *}$ & $0.020^{\star * *}$ & $0.020^{\star * *}$ & $0.027^{\star * *}$ \\
\hline & $(0.004)$ & $(0.004)$ & $(0.006)$ & $(0.004)$ & $(0.004)$ & $(0.006)$ \\
\hline Observations & 2356 & 2365 & 1287 & 2356 & 2365 & 1287 \\
\hline Adjusted R-squared & 0.454 & 0.447 & 0.554 & 0.455 & 0.447 & 0.556 \\
\hline
\end{tabular}

Robust standard errors in parentheses. ${ }^{* *} \mathrm{p}<0.01,{ }^{* *} \mathrm{p}<0.05,{ }^{*} \mathrm{p}<0.1$. 
Therefore, we argue that with a higher level of financial development, there is significant and positive net inflow of capital in the case of portfolio flows. These results provide support for the theoretical preposition of Antras and Caballero [5]. We also observe that GDP still has a consistently positive impact on portfolio flows. When trade is allowed in countries, capital flows in the form of portfolio flows will complement trade and flow more into sectors that have comparative advantage. Hence the positive and significant sign on all the interaction we observe when we use different indicators of the level of financial development ${ }^{15}$. We also notice that the trade liberalisation indicator is significantly negative for almost all estimations. This provides support for our argument about the importance of the financial system for positive net portfolio equity flow into countries that have opened up for trade liberalisation.

Table 11 provides evidence for the behaviour of net FDI inflow and the Chinn-Ito index when we control for the level of financial development. In the case of net FDI inflows, we observe that all the interaction terms are insignificant for all the three indicators of the level of financial development. This outcome is expected as the FDI flows come in form that do not necessary require the financial system. As argued by Ju and Wei [8], FDI goes to countries where the marginal return for physical capital is high and not necessarily where the level of financial system development is high. MNC are able to invest in countries with low levels of development of their financial system as they rely on their parent company as well as the financial system of their parent based company especially for financial support and hence overcome the financial constraints that these low developing countries might pose. Manova [32] provide evidence in the case of China, a country that has slightly low financial development, where FDI provides the main avenue for overcoming credit constraint. A similar outcome is shown by Antras et al. [14] in their study on MNC. In the case of the trade liberalisation indicator, we observe an opposite sign compared to the portfolio flows. The positive significant coefficients indicate a positive net flow of FDI when trade liberalisation is allowed. We observe a similar outcome for the Chinn-Ito index. All the financial development interactions were insignificant but the trade liberalisation was significant in all case. The sizes of the coefficients on the TLIB are larger than those of the interactions which were insignificant and negative in most cases. The overall effect will, therefore, be positive. This confirms the role of trade opening impacting the FDI inflows positively and not necessarily financial development. The correlation analysis above showed that for non-OECD, there is a positive correlation between FDI and the Chinn-Ito index. Once again, a careful look at the constituent component used in constructing this index would expect it to be biased towards FDI flows especially the export criteria in its computation.

To test the robustness of our results, we re-estimate our baseline equation by ${ }^{15} \mathrm{We}$ also observe that the trade liberalisation indicator remains approximately close to 0 and insignificant for the estimation for developing countries only in tables found in the Appendix. 
Table 11. Capital flows and trade for the whole sample: baseline regression.

\begin{tabular}{|c|c|c|c|c|c|c|}
\hline VARIABLES & $\begin{array}{l}\text { Chinn-Ito } \\
\text { index }\end{array}$ & $\begin{array}{l}\text { Chinn-Ito } \\
\text { index }\end{array}$ & $\begin{array}{l}\text { Chinn-Ito } \\
\text { index }\end{array}$ & FDI flows & FDI flows & FDI flows \\
\hline \multirow[t]{2}{*}{ FINDEV1 } & 0.521 & & & 1.915 & & \\
\hline & $(0.339)$ & & & $(1.912)$ & & \\
\hline \multirow[t]{2}{*}{ FINDEV $1 \times$ TLIB } & 0.016 & & & -1.038 & & \\
\hline & $(0.334)$ & & & $(1.843)$ & & \\
\hline \multirow[t]{2}{*}{ FINDEV2 } & & 0.375 & & & 0.970 & \\
\hline & & $(0.315)$ & & & $(1.465)$ & \\
\hline \multirow[t]{2}{*}{ FINDEV $2 \times$ TLIB } & & -0.138 & & & -0.384 & \\
\hline & & $(0.299)$ & & & $(1.390)$ & \\
\hline \multirow[t]{2}{*}{ FINDEV3 } & & & 0.060 & & & $2.694^{* * *}$ \\
\hline & & & $(0.339)$ & & & $(0.960)$ \\
\hline \multirow[t]{2}{*}{ FINDEV $3 \times$ TLIB } & & & -0.143 & & & -0.383 \\
\hline & & & $(0.315)$ & & & $(0.884)$ \\
\hline \multirow[t]{3}{*}{ TLIB } & $0.317^{\star \star \star}$ & $0.328^{\star * *}$ & $0.468^{* * *}$ & 0.553 & 0.377 & $0.530^{* *}$ \\
\hline & $(0.115)$ & $(0.119)$ & $(0.139)$ & $(0.413)$ & $(0.382)$ & $(0.236)$ \\
\hline & \multicolumn{6}{|c|}{ Controls: country, year fixed effects, gdp } \\
\hline Observations & 2301 & 2310 & 1273 & 2284 & 2293 & 1250 \\
\hline Adjusted R-squared & 0.761 & 0.761 & 0.793 & 0.503 & 0.503 & 0.556 \\
\hline
\end{tabular}

Robust standard errors in parentheses. ${ }^{* *} \mathrm{p}<0.01,{ }^{* *} \mathrm{p}<0.05,{ }^{*} \mathrm{p}<0.1$

including some macroeconomic and institutional variables ${ }^{16}$.

From Table 12, we observe that all interactions term of financial development with trade openness are positive and significant for the two indicators of portfolio flow in the presence of the other controls. This confirms our earlier results of the important role of financial development for capital flows in the form of portfolio flows. The coefficient of the constituent term, TLIB comes significant and negative implying that in the absence of a good financial system, we expect that capital will flow out ${ }^{17}$. The constituent term, FINDEV mostly produces a positive coefficient though insignificant.

In a few cases where it was negative the interaction term effect was larger, hence making the overall effect positive on portfolio flows. The institutional variables in the case of corruption were positive for almost all and significant in a few cases. As expected, when the corruption ${ }^{18}$ level decreases we expect that it

\footnotetext{
${ }^{16}$ Some of the macroeconomic variables were not significant and hence we do not show them on the result table. A similar pattern is observed in most of the literature including Alfaro et al. [33], Aizenman and Noy [5], Chinn and Ito [19].

${ }^{17}$ Especially in the case of the developing countries estimation in the appendix Table A3, the coefficient of constituent term, TLIB still remains close to zero and insignificant confirming that it plays no role in the absence of a good financial system.

${ }^{18}$ The corruption indicator is constructed in a way that the higher the indicator the lower the level of corruption.
} 
Table 12. Capital flows and trade for whole sample: robustness.

\begin{tabular}{|c|c|c|c|c|c|c|}
\hline VARIABLES & $\begin{array}{c}\text { Portfolio } \\
\text { flows } 2\end{array}$ & $\begin{array}{c}\text { Portfolio } \\
\text { flows } 2\end{array}$ & $\begin{array}{c}\text { Portfolio } \\
\text { flows } 2\end{array}$ & $\begin{array}{c}\text { Portfolio } \\
\text { flows } 1\end{array}$ & $\begin{array}{l}\text { Portfolio } \\
\text { flows } 1\end{array}$ & $\begin{array}{c}\text { Portfolio } \\
\text { flows } 1\end{array}$ \\
\hline \multirow[t]{2}{*}{ FINDEV1 } & $0.342^{*}$ & & & $0.332^{*}$ & & \\
\hline & $(0.183)$ & & & $(0.181)$ & & \\
\hline \multirow[t]{2}{*}{ FINDEV $1 \times$ TLIB } & $0.558^{* * *}$ & & & $0.544^{\star * *}$ & & \\
\hline & $(0.143)$ & & & $(0.141)$ & & \\
\hline \multirow[t]{2}{*}{ FINDEV2 } & & 0.030 & & & 0.018 & \\
\hline & & $(0.234)$ & & & $(0.233)$ & \\
\hline \multirow[t]{2}{*}{ FINDEV $2 \times$ TLIB } & & $0.246^{* *}$ & & & $0.228^{*}$ & \\
\hline & & $(0.118)$ & & & $(0.117)$ & \\
\hline \multirow[t]{2}{*}{ FINDEV3 } & & & -0.247 & & & -0.301 \\
\hline & & & $(0.376)$ & & & $(0.381)$ \\
\hline \multirow[t]{2}{*}{ FINDEV $3 \times$ TLIB } & & & $0.616^{*}$ & & & $0.656^{*}$ \\
\hline & & & $(0.342)$ & & & $(0.349)$ \\
\hline \multirow[t]{2}{*}{ TLIB } & $-0.225^{* * *}$ & $-0.243^{* * *}$ & -0.043 & $-0.242^{* * *}$ & $-0.258^{\star * *}$ & $-0.122^{\star *}$ \\
\hline & $(0.058)$ & $(0.062)$ & $(0.063)$ & $(0.058)$ & $(0.061)$ & $(0.060)$ \\
\hline \multirow[t]{2}{*}{ Corruption index } & $0.376^{* * *}$ & $0.367^{* * *}$ & $0.491^{* * *}$ & $0.376^{\star * *}$ & $0.368^{\star * *}$ & $0.473^{\star * *}$ \\
\hline & $(0.075)$ & $(0.075)$ & $(0.138)$ & $(0.074)$ & $(0.075)$ & $(0.137)$ \\
\hline \multirow[t]{3}{*}{ Rule of law } & $-3.232^{* * *}$ & $-3.152^{* * *}$ & $-5.567^{\star * *}$ & $-3.233^{* * *}$ & $-3.157^{\star * *}$ & $-5.512^{* * *}$ \\
\hline & $(0.655)$ & $(0.662)$ & $(1.300)$ & $(0.655)$ & $(0.662)$ & $(1.296)$ \\
\hline & \multicolumn{6}{|c|}{ country, year fixed effects, gdp, interest rate, inflation } \\
\hline Observations & 1973 & 1982 & 1159 & 1973 & 1982 & 1159 \\
\hline $\begin{array}{c}\text { Adjusted } \\
\text { R-squared }\end{array}$ & 0.454 & 0.446 & 0.553 & 0.454 & 0.447 & 0.556 \\
\hline
\end{tabular}

Robust standard errors in parentheses. ${ }^{* *} \mathrm{p}<0.01,{ }^{* *} \mathrm{p}<0.05,{ }^{*} \mathrm{p}<0.1$.

will encourage more inflows. Rule of law measuring the importance of the democratic environment shows up significant and positive in few cases as expected. In the case of FDI and the Chinn-Ito index, as expected and obtained in the baseline regression, the interaction terms are insignificant in all cases and even showed with a negative sign in some cases. This supports the argument that FDI inflows do not necessary rely immensely on the financial system. Once a country is open, capital flow in the form of FDI will flow in not necessarily because of the level of development of the financial system as we observe a non-significant positive coefficient on the constituent term of the interaction. Institutional behaviour might be more important for FDI inflow. TLIB as a constituent term is significant and positive in most cases for the index and FDI. As has been argued, the presence of FDI flows can result in a complete bypass of the financial system [8].

For sensitivity analysis, we introduce a new variable to replace our measure of 
trade liberalisation. Trade as a percentage of GDP is used in the literature to capture openness ${ }^{19}$. We interact this variable with our measures of financial development and observe how this influences the different types of capital flows. From Table 13 and Table 14, the results show a consistent pattern as obtain in previous results where portfolio flows is positively influenced by interaction between trade openness and the level of financial development as well as FDI flows which still remain insignificant. However, the interaction term in the case of Chinn-Ito index becomes significant but negative (Table 15).

\section{Endogeneity Concerns}

The issue of endogeneity can create a lot of methodological problems in this area

Table 13. Capital flows and trade for the whole sample.

\begin{tabular}{|c|c|c|c|c|c|c|}
\hline VARIABLES & $\begin{array}{l}\text { Chinn-Ito } \\
\text { index }\end{array}$ & $\begin{array}{c}\text { Chinn-Ito } \\
\text { index }\end{array}$ & $\begin{array}{l}\text { Chinn-Ito } \\
\text { index }\end{array}$ & FDI flows & FDI flows & FDI flows \\
\hline FINDEV1 & $\begin{array}{c}0.588 \\
(0.366)\end{array}$ & & & $\begin{array}{c}1.964 \\
(2.043)\end{array}$ & & \\
\hline FINDEV1 $\times$ TLIB & $\begin{array}{l}-0.159 \\
(0.360)\end{array}$ & & & $\begin{array}{l}-1.159 \\
(1.970)\end{array}$ & & \\
\hline FINDEV2 & & $\begin{array}{l}0.564^{*} \\
(0.338)\end{array}$ & & & $\begin{array}{l}1.045 \\
(1.535)\end{array}$ & \\
\hline FINDEV2 $\times$ TLIB & & $\begin{array}{l}-0.386 \\
(0.321)\end{array}$ & & & $\begin{array}{l}-0.534 \\
(1.457)\end{array}$ & \\
\hline FINDEV3 & & & $\begin{array}{c}0.093 \\
(0.337)\end{array}$ & & & $\begin{array}{c}2.757^{\star * *} \\
(0.905)\end{array}$ \\
\hline FINDEV3 $\times$ TLIB & & & $\begin{array}{l}-0.165 \\
(0.312)\end{array}$ & & & $\begin{array}{l}-0.512 \\
(0.825)\end{array}$ \\
\hline TLIB & $\begin{array}{c}0.414^{* * *} \\
(0.127)\end{array}$ & $\begin{array}{c}0.456^{* * *} \\
(0.132)\end{array}$ & $\begin{array}{c}0.493^{* * *} \\
(0.146)\end{array}$ & $\begin{array}{l}0.569 \\
(0.442)\end{array}$ & $\begin{array}{c}0.401 \\
(0.407)\end{array}$ & $\begin{array}{l}0.502^{\star *} \\
(0.236)\end{array}$ \\
\hline Corrupt & $\begin{array}{c}0.269^{* * *} \\
(0.060)\end{array}$ & $\begin{array}{c}0.264^{* * *} \\
(0.060)\end{array}$ & $\begin{array}{c}-0.504^{* * *} \\
(0.048)\end{array}$ & $\begin{array}{l}0.462^{* * *} \\
(0.069)\end{array}$ & $\begin{array}{c}0.450^{* * *} \\
(0.070)\end{array}$ & $\begin{array}{c}-1.277^{* * *} \\
(0.200)\end{array}$ \\
\hline Rule law & $\begin{array}{c}0.870^{* * *} \\
(0.113)\end{array}$ & $\begin{array}{l}0.906^{\star * \star} \\
(0.110)\end{array}$ & $\begin{array}{l}2.124^{\star * \star} \\
(0.178)\end{array}$ & $\begin{array}{c}0.249 \\
(0.213)\end{array}$ & $\begin{array}{c}0.346 \\
(0.218)\end{array}$ & $\begin{array}{l}2.317^{* * *} \\
(0.425)\end{array}$ \\
\hline
\end{tabular}

country, year fixed effects, gdp country, year fixed effects, gdp, interest rate, inflation

\begin{tabular}{ccccccc} 
Observations & 1933 & 1942 & 1147 & 1905 & 1914 & 1123 \\
$\begin{array}{c}\text { Adjusted } \\
\text { R-squared }\end{array}$ & 0.762 & 0.762 & 0.789 & 0.497 & 0.498 & 0.558 \\
\hline
\end{tabular}

Robust standard errors in parentheses. ${ }^{* *} \mathrm{p}<0.01,{ }^{* *} \mathrm{p}<0.05,{ }^{*} \mathrm{p}<0.1$.

${ }^{19}$ See Aizenman and Noy [5], Chinn and Ito [19] for similar use of the same variable as a measure of trade openness. 
Table 14. Capital flows and trade for the whole sample: sensitivity analysis.

\begin{tabular}{|c|c|c|c|c|c|c|}
\hline VARIABLES & $\begin{array}{c}\text { Portfolio } \\
\text { flows } 2\end{array}$ & $\begin{array}{c}\text { Portfolio } \\
\text { flows } 2\end{array}$ & $\begin{array}{c}\text { Portfolio } \\
\text { flows } 2\end{array}$ & $\begin{array}{c}\text { Portfolio } \\
\text { flows } 1\end{array}$ & $\begin{array}{c}\text { Portfolio } \\
\text { flows } 1\end{array}$ & $\begin{array}{c}\text { Portfolio } \\
\text { flows } 1\end{array}$ \\
\hline \multirow[t]{2}{*}{ FINDEV1 } & $-0.836^{* *}$ & & & $-0.887^{\star *}$ & & \\
\hline & $(0.386)$ & & & $(0.386)$ & & \\
\hline \multirow[t]{2}{*}{ FINDEV $1 \times$ TLIB } & $0.017^{\star * *}$ & & & $0.017^{* * *}$ & & \\
\hline & $(0.005)$ & & & $(0.005)$ & & \\
\hline \multirow[t]{2}{*}{ TLIB } & -0.003 & -0.002 & -0.003 & $-0.003^{*}$ & -0.002 & 0.003 \\
\hline & $(0.002)$ & $(0.003)$ & $(0.002)$ & $(0.002)$ & $(0.003)$ & $(0.002)$ \\
\hline \multirow[t]{2}{*}{ FINDEV2 } & & -0.934 & & & -0.973 & \\
\hline & & $(0.627)$ & & & $(0.626)$ & \\
\hline \multirow[t]{2}{*}{ FINDEV $2 \times$ TLIB } & & $0.012^{* * *}$ & & & $0.012^{* * *}$ & \\
\hline & & $(0.004)$ & & & $(0.004)$ & \\
\hline \multirow[t]{2}{*}{ FINDEV3 } & & & 0.707 & & & 0.728 \\
\hline & & & $(0.455)$ & & & $(0.455)$ \\
\hline \multirow[t]{2}{*}{ FINDEV $3 \times$ TLIB } & & & $0.004^{\star}$ & & & $0.005^{*}$ \\
\hline & & & $(0.002)$ & & & $(0.002)$ \\
\hline
\end{tabular}

Controls. country, year fixed effects, gdp, rule law, corrupt, interest rate, inflation

\begin{tabular}{ccccccc} 
Observations & 1500 & 1509 & 878 & 1,500 & 1509 & 878 \\
Adjusted R-squared & 0.477 & 0.471 & 0.556 & 0.479 & 0.473 & 0.559 \\
\hline
\end{tabular}

Robust standard errors in parentheses. ${ }^{* * *} \mathrm{p}<0.01,{ }^{* *} \mathrm{p}<0.05,{ }^{*} \mathrm{p}<0.1$.

Table 15. Capital flows and trade for the whole sample: sensitivity analysis.

\begin{tabular}{ccccccc}
\hline VARIABLES & $\begin{array}{c}\text { Chinn-Ito } \\
\text { index }\end{array}$ & $\begin{array}{c}\text { Chinn-Ito } \\
\text { index }\end{array}$ & $\begin{array}{c}\text { Chinn-Ito } \\
\text { index }\end{array}$ & FDI flows & FDI flows & FDI flows \\
\hline FINDEV1 & $0.991^{* *}$ & & & -1.063 & & \\
& $(0.254)$ & & & $(1.327)$ & & \\
FINDEV1 $\times$ TLIB & $-0.008^{* * *}$ & & & 0.025 & & \\
& $(0.002)$ & & & $(0.017)$ & & \\
TLIB & 0.001 & 0.002 & $-0.011^{* * *}$ & $0.026^{* * *}$ & $0.032^{* * *}$ & 0.005 \\
& $(0.002)$ & $(0.002)$ & $(0.003)$ & $(0.010)$ & $(0.010)$ & $(0.010)$ \\
FINDEV2 & & $0.547^{* * *}$ & & & -0.109 & \\
& & $(0.191)$ & & & $(0.930)$ & \\
FINDEV2 $\times$ TLIB & & $-0.010^{* * *}$ & & 0.010 & \\
& & $(0.002)$ & & & $(0.012)$ & \\
FINDEV3 & & & 0.304 & & & 0.260 \\
& & & $(0.214)$ & & & $(0.676)$ \\
FINDEV3 $\times$ TLIB & & & $-0.003^{*}$ & & & $(0.006)$
\end{tabular}

Controls. country, year fixed effects, gdp, rule law, corrupt, interest rate, inflation

\begin{tabular}{ccccccc} 
Observations & 1468 & 1477 & 867 & 1450 & 1459 & 848 \\
Adjusted R-squared & 0.804 & 0.806 & 0.817 & 0.528 & 0.527 & 0.557 \\
\hline
\end{tabular}

Robust standard errors in parentheses. ${ }^{* *} \mathrm{p}<0.01,{ }^{* *} \mathrm{p}<0.05,{ }^{*} \mathrm{p}<0.1$. 
of study. This can arise through the possibility of reverse causality (Wooldridge, 2002). It is very likely that the level of financial development can be increased by higher level of capital flows. If this is the case, then the estimate above could be biased. However, one could argue that because of the interaction of the financial development with trade liberalisation, it could ameliorate the problem. Given that trade liberalisation is a dummy variable, if on average it takes the value of 0 , then that makes the interaction with financial development produce an outcome that is less likely to be endogenous. Also, endogeneity can arise through the problem of omitted variable bias. This problem is greatly reduced by implementation of the fixed effect model, which captures any time and country specific characteristics.

However, we take a further step to implement a two stage least squares to address the issue of endogeneity. We instrument for the level of financial development in the interaction term in our regression. As required for dealing with endogenous variables, we look for a variable that is related to the level of financial development but uncorrelated with the error term [34]. We use the legal origin variables of each country as instruments for financial development as it is not subject to reverse causality. This variable is obtained from La Porta et al. [29] (LLSV hereafter). In their paper, they showed that legal origin did influence the financial environment. Countries with different legal origin had different legal protection to provide the right ambience for investment through the preservation of shareholders and creditors' right and effective law enforcement. Legal origin status was obtained through colonisation, adoption or occupation and categorised into 4 distinct legal systems; namely: English common law, French civil law, German civil law, and Scandinavian civil law. In the literature, legal origin has been used very often as instrument for financial development [2] [9]. Following Alfaro et al. (2004) we also include as part of our instrument creditors right measure obtain from LLSV [29]. Also, the exclusion restriction is not violated as countries decisions to open for international capital flows are not based on their legal origin but more critically the gains from the interaction and their economic position [35].

We interact the legal origin variable with the trade liberalisation indicator and create a new interaction term. We estimate a 2-Stage Least Squares (2SLS) in cross section as the instrumental variables do not vary over time

From the results in Table 16, we confirm the robustness of our result tables above. We obtain positive and significant interaction terms similar to what we obtained earlier. To confirm the validity of our instrument, we tested for no over-identifying restriction. As observed from the table, the test statistic supports the view that our instruments used in all the regression are valid. From Table 17, we also obtain similar results as expected. In the regression of FDI and Chinn-Ito index, the interaction terms are insignificant. This confirms that FDI flows do not necessary need financially developed countries to flow into as our results have shown. These results have been confirmed by the robustness test 
Table 16. Capital flows and trade for the whole sample: IV regression.

\begin{tabular}{ccccccc}
\hline VARIABLES & $\begin{array}{c}\text { Portfolio } \\
\text { flows 2 }\end{array}$ & $\begin{array}{c}\text { Portfolio } \\
\text { flows 2 }\end{array}$ & $\begin{array}{c}\text { Portfolio } \\
\text { flows 2 }\end{array}$ & $\begin{array}{c}\text { Portfolio } \\
\text { flows 1 }\end{array}$ & $\begin{array}{c}\text { Portfolio } \\
\text { flows 1 }\end{array}$ & $\begin{array}{c}\text { Portfolio } \\
\text { flows 1 }\end{array}$ \\
\hline FINDEV1 $\times$ TLIB & $5.488^{*}$ & & & $5.476^{*}$ & & \\
& $(3.322)$ & & & $(3.318)$ & & \\
FINDEV2 $\times$ TLIB & & $1.422^{*}$ & & & $1.512^{* *}$ & \\
& & $(0.746)$ & & & $(0.757)$ & \\
FINDEV3 $\times$ TLIB & & & $12.379^{*}$ & & & $12.146^{*}$ \\
& & & $(7.140)$ & & & $(7.085)$
\end{tabular}

Controls. FINDEV1, TLIB, gdp, rule law, corrupt, interest rate, inflation

\begin{tabular}{ccccccc} 
Observations & 92 & 92 & 70 & 92 & 92 & 70 \\
$\begin{array}{c}\text { Adjusted } \\
\text { R-squared }\end{array}$ & 0.30 & 0.315 & 0.15 & 0.32 & 0.307 & 0.12 \\
OIR test & 0.332 & 2.091 & 0.644 & 0.341 & 3.614 & 0.588 \\
Prob & 0.847 & 0.719 & 0.968 & 0.843 & 0.461 & 0.971 \\
\hline
\end{tabular}

Robust standard errors in parentheses. ${ }^{* * *} \mathrm{p}<0.01,{ }^{* *} \mathrm{p}<0.05,{ }^{*} \mathrm{p}<0.1$.

Table 17. Capital flows and trade for the whole sample: IV regression.

\begin{tabular}{ccccccc}
\hline VARIABLES & $\begin{array}{c}\text { Chinn-Ito } \\
\text { index }\end{array}$ & $\begin{array}{c}\text { Chinn-Ito } \\
\text { index }\end{array}$ & $\begin{array}{c}\text { Chinn-Ito } \\
\text { index }\end{array}$ & FDI flows & FDI flows & FDI flows \\
\hline FINDEV1 $\times$ TLIB & 2.786 & & & 1.30 & & \\
& $(2.993)$ & & & $(9.967)$ & & \\
FINDEV2 $\times$ TLIB & & 1.838 & & & 0.761 & \\
& & $(1.902)$ & & & $(2.933)$ & \\
FINDEV3 $\times$ TLIB & & & -0.03 & & & 0.91 \\
& & & $(9.590)$ & & & $(18.185)$
\end{tabular}

Controls: FINDEV1, TLIB, gdp, rule law, corrupt, interest rate, inflation

\begin{tabular}{ccccccc}
$\begin{array}{c}\text { Observations } \\
\text { Adjusted }\end{array}$ & 92 & 92 & 70 & 92 & 92 & 70 \\
$\begin{array}{c}\text { R-squared } \\
\text { OIR test }\end{array}$ & 0.477 & 0.497 & 0.352 & 0.065 & 0.067 & 0.120 \\
Prob & 0.408 & 1.811 & 2.204 & 0.605 & 5.135 & 1.931 \\
\hline
\end{tabular}

Robust standard errors in parentheses. ${ }^{* *} \mathrm{p}<0.01,{ }^{* *} \mathrm{p}<0.05,{ }^{\star} \mathrm{p}<0.1$.

using the IV estimations. Once again, the null hypothesis of no over-identifying restriction is not rejected as all the P-values showed that it is statistically insignificant.

\section{Conclusion}

The current rate of globalisation requires a better understanding of financial integration and its impact on the domestic economy. In this paper we contribute 
to this area of study by examining the relationship between trade flows and capital flows and how financial development could influence this relationship. Using a panel of 130 countries from 1980 to 2005 we examine this relationship. We examine this relationship for 4 different types of capital flows. Our results show that portfolio flows can flow into the country when they improve their financial system. Such improvement influences the return on financial capital and hence such economies can attract more capital inflows which can positively affect the domestic economy. More capital is made available for firms to expand production and the countries growth is affected positively. For FDI flows our results show that as a country opens up for trade FDI will flow even in the absence of a strong financial system. This is because FDI targets places where return on physical capital is highest. Most of these FDI firms tend to rely on their parent company or the financial system of their parent company (Antras et al., 2009). Also, most of the outputs by FDI firms finally end up on the international market through export. This can results in the complete by-pass of the financial system in the domestic economy. It is therefore important as a policy recommendation for countries to enact policies to encourage joint partnership of FDI firms with the domestic firms. Also policies could encourage the use of the domestic financial system by FDI firms.

\section{Acknowledgements}

I would like to thank participants at various seminars and in particular Alessandra Guariglia, Fabrice Defever, Spiros Bougheas, and Zhihong Yu for their helpful comments and suggestions.

\section{Conflicts of Interest}

The author declares no conflicts of interest regarding the publication of this paper.

\section{References}

[1] Beck, T. (2003) Financial Dependence and International Trade. Review of International Economics, 11, 296-316. https://doi.org/10.1111/1467-9396.00384

[2] Beck, T. (2002) Financial Development and International Trade Is There a Link? Journal of International Economics, 57, 107-131. https://doi.org/10.1016/S0022-1996(01)00131-3

[3] Blonigen, B. (2005) A Review of the Empirical Literature on FDI Determinants. Atlantic Economic Journal, 33, 383-403. https://doi.org/10.1007/s11293-005-2868-9

[4] Antras, P. and Caballero, R.J. (2009) Trade and Capital Flows: A Financial Frictions Perspective. Journal of Political Economy, 117, 701-744. https://doi.org/10.1086/605583

[5] Aizenman, J. and Noy, I. (2009) Endogenous Financial and Trade Openness. Review of Development Economics, 13, 175-189. https://doi.org/10.1111/j.1467-9361.2008.00488.x

[6] Matsuyama, K. (2004) Credit Market Imperfections and Patterns of International Trade and Capital Flows. Journal of European Economic Association, 3, 714-723. 
https://doi.org/10.1162/jeea.2005.3.2-3.714

[7] Manova, K., Wei, S.J. and Zhang, Z. (2015) Firm Exports and Multinational Activity under Credit Constraints. Review of Economics and Statistics, 97, 574-588. https://doi.org/10.1162/REST_a_00480

[8] Ju, J. and Wei, S-J. (2011) When Is Quality of Financial System a Source of Comparative Advantage? Journal of International Economics, 84, 178-187. https://doi.org/10.1016/j.jinteco.2011.03.004

[9] Alfaro, L., Chanda, A., Kalemli-Ozcan, S. and Sayek, S. (2004) FDI and Economic Growth: The Role of Local Financial Markets. Journal of International Economics, 64, 89-112. https://doi.org/10.1016/S0022-1996(03)00081-3

[10] Hsieh, C.T. and Klenow, P.J. (2007) Relative Prices and Relative Prosperity. American Economic Review, 97, 562-585. https://doi.org/10.1257/aer.97.3.562

[11] Egger, H. and Kreickemeier, U. (2009) Firm Heterogeneity and the Labour Market Effects of Trade Liberalisation. International Economic Review, 50, 187-216. https://doi.org/10.1111/j.1468-2354.2008.00527.x

[12] Caselli, F. (2005) Accounting for Cross-Country Income Differences. In: Aghion, P. and Durlauf, S., Eds., Handbook of Economic Growth, Volume 1, Chapter 9, Elsevier, Amsterdam, 679-741.

[13] Caves, R.E. (1996) Multinational Enterprise and Economic Analysis. 2nd Edition, Cambridge University Press, Cambridge, New York and Melbourne.

[14] Antras, P., Desai, M. and Foley, C.F. (2009) Multinational Firms, FDI Flows and Imperfect Capital Markets. Quarterly Journal of Economics, 124, 1171-1219. https://doi.org/10.1162/qjec.2009.124.3.1171

[15] Tornell, A., Westermann, F. and Martinez, L. (2004) The Positive Link between Financial Liberalisation, Growth and Crises. NBER Working Papers 10293, National Bureau of Economic Research, Inc.

[16] Aizenman, J. and Noy, I. (2006) FDI and Trade-Two-Way Linkages? The Quarterly Review of Economics and Finance, 46, 317-337. https://doi.org/10.1016/j.qref.2006.02.004

[17] Chinn, M.D. and Ito, H. (2006) What Matters for Financial Development? Capital Controls, Institutions, and Interactions. Journal of Development Economics, 81, 163-192. https://doi.org/10.1016/j.jdeveco.2005.05.010

[18] Klein, M.W. and Olivei, G. (2008) Capital Account Liberalisation, Financial Depth, and Economic Growth. Journal of International Money and Finance, 27, 861-875. https://doi.org/10.1016/j.jimonfin.2008.05.002

[19] Chinn, M.D. and Ito, H. (2002) Capital Account Liberalization, Institutions and Financial Development: Cross Country Evidence. NBER Working Papers 8967, National Bureau of Economic Research, Inc.

[20] De Gregorio, J. (1999) Financial Integration, Financial Development and Economic Growth. Estudios de Economia, 26, 137-161.

[21] Beck, D.K., Demirguc-Kunt, A. and Levine, R. (2000) A New Database on the Structure and Development of the Financial Sector. World Bank Economic Review, 14, 597-605. https://doi.org/10.1093/wber/14.3.597

[22] The World Bank (2018) World Development Indicators. Washington DC.

[23] Levine, R. (1997) Financial Development and Economic Growth: Views and Agenda. Journal of Economic Literature, 35, 688-726.

[24] Mody, A. and Murshid, A.P. (2005) Growing Up with Capital Flows. Journal of International Economics, 65, 249-266. https://doi.org/10.1016/j.jinteco.2004.02.003 
[25] Wacziarg, R. and Welch, K.H. (2008) Trade Liberalization and Growth: New Evidence. The World Bank Economic Review, 22, 187-231. https://doi.org/10.1093/wber/lhn007

[26] Sachs, J.D., Warner, A., Åslund, A. and Fischer, S. (1995) Economic Reform and the Process of Global Integration. Brookings Papers on Economic Activity, 1, 1-118. https://doi.org/10.2307/2534573

[27] Zingales, L. and Rajan, R.G. (2003) The Great Reversals: The Politics of Financial Development in the Twentieth Century. Journal of Financial Economics, 69, 5-50. https://doi.org/10.1016/S0304-405X(03)00125-9

[28] Milner, C. and Williamson, J. (1991) The World Economy: A Textbook in International Economics. Harvester Wheatsheaf, Loughborough.

[29] La Porta, R., Lopez-de-Silanes, F., Shleifer, A. and Vishny, R.W. (1997) Legal Determinants of External Finance. Journal of Finance, 55, 1131-1150. https://doi.org/10.1111/j.1540-6261.1997.tb02727.x

[30] Kose, M.A., Prasad, E., Rogoff, K.S. and Wei, S.J. (2006) Financial Globalization: A Reappraisal (No. w12484). National Bureau of Economic Research. https://doi.org/10.3386/w12484

[31] Forbes, K.J. (2010) Why Do Foreigners Invest in the United States? Journal of International Economics, 80, 3-21. https://doi.org/10.1016/j.jinteco.2009.09.001

[32] Manova, K. (2008) Credit Constraints, Equity Market Liberalizations and International Trade. Journal of International Economics, 76, 33-47. https://doi.org/10.1016/j.jinteco.2008.03.008

[33] Alfaro, L., Kalemli-Ozcan, S. and Volosovych, V. (2008) Why Doesn't Capital Flow from Rich to Poor Countries? An Empirical Investigation. The Review of Economics and Statistics, 90, 347-368. https://doi.org/10.1162/rest.90.2.347

[34] Wooldridge, J. (2002) Econometric Analysis of Cross Section and Panel Data. MIT Press, Cambridge.

[35] Sarno, L., Tsiakas, I. and Ulloa, B. (2016) What Drives International Portfolio Flows? Journal of International Money and Finance, 60, 53-72. 


\section{Appendix}

Table A1. Capital flows and trade for developing countries: baseline regression.

\begin{tabular}{|c|c|c|c|c|c|c|}
\hline DEP VARIABLES & $\begin{array}{c}\text { Portfolio } \\
\text { flows } 2\end{array}$ & $\begin{array}{c}\text { Portfolio } \\
\text { flows } 2\end{array}$ & $\begin{array}{c}\text { Portfolio } \\
\text { flows } 2\end{array}$ & $\begin{array}{l}\text { Portfolio } \\
\text { flows } 1\end{array}$ & $\begin{array}{c}\text { Portfolio } \\
\text { flows } 1\end{array}$ & $\begin{array}{c}\text { Portfolio } \\
\text { flows } 1\end{array}$ \\
\hline \multirow[t]{2}{*}{ FINDEV1 } & -0.001 & & & -0.044 & & \\
\hline & $(0.041)$ & & & $(0.032)$ & & \\
\hline \multirow[t]{2}{*}{ FINDEV $1 \times$ TLIB } & $0.157^{\star * *}$ & & & $0.125^{\star * \star}$ & & \\
\hline & $(0.045)$ & & & $(0.041)$ & & \\
\hline \multirow[t]{2}{*}{ FINDEV2 } & & 0.026 & & & -0.013 & \\
\hline & & $(0.036)$ & & & $(0.026)$ & \\
\hline \multirow[t]{2}{*}{ FINDEV $2 \times$ TLIB } & & $0.142^{* * *}$ & & & $0.112^{* * *}$ & \\
\hline & & $(0.045)$ & & & $(0.042)$ & \\
\hline \multirow[t]{2}{*}{ FINDEV3 } & & & $-0.170^{*}$ & & & $-0.176^{\star *}$ \\
\hline & & & $(0.089)$ & & & $(0.075)$ \\
\hline \multirow[t]{2}{*}{ FINDEV $3 \times$ TLIB } & & & $0.226^{* * *}$ & & & $0.220^{* * *}$ \\
\hline & & & $(0.083)$ & & & $(0.072)$ \\
\hline \multirow[t]{2}{*}{ TLIB } & 0.000 & 0.000 & $0.071^{\star \star \star}$ & 0.011 & 0.011 & 0.010 \\
\hline & $(0.012)$ & $(0.013)$ & $(0.026)$ & $(0.008)$ & $(0.009)$ & $(0.016)$ \\
\hline \multirow[t]{3}{*}{$\operatorname{lgdp}$} & $0.016^{\star * *}$ & $0.016^{* * *}$ & $0.015^{\star * *}$ & $0.011^{\star * *}$ & $0.011^{\star * *}$ & $0.013^{* * *}$ \\
\hline & $(0.003)$ & $(0.003)$ & $(0.003)$ & $(0.003)$ & $(0.003)$ & $(0.002)$ \\
\hline & \multicolumn{6}{|c|}{ Controls: country, year fixed effects } \\
\hline Observations & 1823 & 1830 & 922 & 1823 & 1830 & 922 \\
\hline Adjusted R-squared & 0.449 & 0.451 & 0.500 & 0.377 & 0.375 & 0.500 \\
\hline
\end{tabular}

Robust standard errors in parentheses. ${ }^{* *} \mathrm{p}<0.01,{ }^{* *} \mathrm{p}<0.05,{ }^{*} \mathrm{p}<0.1$.

Table A2. Capital flows and trade for developing countries: baseline regression.

\begin{tabular}{|c|c|c|c|c|c|c|}
\hline VARIABLES & $\begin{array}{l}\text { Chinn-Ito } \\
\text { index }\end{array}$ & $\begin{array}{l}\text { Chinn-Ito } \\
\text { index }\end{array}$ & $\begin{array}{c}\text { Chinn-Ito } \\
\text { index }\end{array}$ & FDI flows & FDI flows & FDI flows \\
\hline \multirow[t]{2}{*}{ FINDEV 1} & 0.465 & & & 2.319 & & \\
\hline & $(0.336)$ & & & $(2.003)$ & & \\
\hline \multirow{2}{*}{ FINDEV1 $\times$ TLIB } & -0.232 & & & -0.945 & & \\
\hline & $(0.334)$ & & & $(1.777)$ & & \\
\hline \multirow[t]{2}{*}{ FINDEV2 } & & 0.238 & & & 1.180 & \\
\hline & & $(0.312)$ & & & $(1.528)$ & \\
\hline \multirow[t]{2}{*}{ FINDEV $2 \times$ TLIB } & & -0.368 & & & -0.304 & \\
\hline & & $(0.285)$ & & & $(1.364)$ & \\
\hline \multirow[t]{2}{*}{ FINDEV3 } & & & 0.232 & & & $2.889^{* * *}$ \\
\hline & & & $(0.378)$ & & & $(1.103)$ \\
\hline \multirow[t]{2}{*}{ FINDEV $3 \times$ TLIB } & & & -0.409 & & & -0.987 \\
\hline & & & $(0.335)$ & & & $(0.981)$ \\
\hline
\end{tabular}




\section{Continued}

\begin{tabular}{ccccccc}
\hline TLIB & $0.584^{* * *}$ & $0.611^{* * *}$ & $0.680^{* * *}$ & $0.753^{*}$ & $0.605^{*}$ & 0.387 \\
& $(0.125)$ & $(0.125)$ & $(0.145)$ & $(0.397)$ & $(0.363)$ & $(0.250)$ \\
& & \multicolumn{7}{c}{ Controls: country, year fixed effects, gdp } \\
Observations & 1785 & 1792 & 915 & 1774 & 1781 & 899 \\
Adjusted R-squared & 0.704 & 0.705 & 0.729 & 0.564 & 0.563 & 0.660 \\
\hline
\end{tabular}

Robust standard errors in parentheses. ${ }^{\star * *} \mathrm{p}<0.01,{ }^{* *} \mathrm{p}<0.05,{ }^{\star} \mathrm{p}<0.1$.

Table A3. Capital flows and trade for developing countries: baseline regression.

\begin{tabular}{|c|c|c|c|c|c|c|}
\hline VARIABLES & $\begin{array}{c}\text { Portfolio } \\
\text { flows } 2\end{array}$ & $\begin{array}{c}\text { Portfolio } \\
\text { flows } 2\end{array}$ & $\begin{array}{c}\text { Portfolio } \\
\text { flows } 2\end{array}$ & $\begin{array}{c}\text { Portfolio } \\
\text { flows } 1\end{array}$ & $\begin{array}{c}\text { Portfolio } \\
\text { flows } 1\end{array}$ & $\begin{array}{c}\text { Portfolio } \\
\text { flows } 1\end{array}$ \\
\hline \multirow[t]{2}{*}{ FINDEV1 } & 0.012 & & & -0.041 & & \\
\hline & $(0.045)$ & & & $(0.035)$ & & \\
\hline \multirow[t]{2}{*}{ FINDEV $1 \times$ TLIB } & $0.163^{\star \star *}$ & & & $0.132^{* * *}$ & & \\
\hline & $(0.049)$ & & & $(0.044)$ & & \\
\hline \multirow[t]{2}{*}{ FINDEV2 } & & 0.040 & & & -0.007 & \\
\hline & & $(0.039)$ & & & $(0.028)$ & \\
\hline \multirow[t]{2}{*}{ FINDEV $2 \times$ TLIB } & & $0.139^{* * *}$ & & & $0.114^{\star * *}$ & \\
\hline & & $(0.048)$ & & & $(0.044)$ & \\
\hline \multirow[t]{2}{*}{ FINDEV3 } & & & $-0.164^{*}$ & & & $-0.179^{\star *}$ \\
\hline & & & $(0.093)$ & & & $(0.078)$ \\
\hline \multirow[t]{2}{*}{ FINDEV3 $\times$ TLIB } & & & $0.220^{* *}$ & & & $0.222^{* * *}$ \\
\hline & & & $(0.086)$ & & & $(0.075)$ \\
\hline \multirow[t]{2}{*}{ TLIB } & 0.005 & 0.006 & $0.078^{\star * *}$ & -0.009 & -0.009 & 0.013 \\
\hline & $(0.014)$ & $(0.015)$ & $(0.027)$ & $(0.010)$ & $(0.011)$ & $(0.017)$ \\
\hline \multirow[t]{2}{*}{ corrupt } & $0.010^{* * *}$ & 0.001 & 0.014 & $0.007^{\star * *}$ & 0.004 & 0.011 \\
\hline & $(0.003)$ & $(0.010)$ & $(0.023)$ & $(0.003)$ & $(0.010)$ & $(0.021)$ \\
\hline \multirow[t]{2}{*}{ rulelaw } & -0.012 & 0.002 & $-0.045^{\star}$ & -0.003 & 0.002 & -0.021 \\
\hline & $(0.008)$ & $(0.018)$ & $(0.023)$ & $(0.004)$ & $(0.017)$ & $(0.019)$ \\
\hline
\end{tabular}

Controls: country, year fixed effects, gdp, interest rate, inflation rate

$\begin{array}{ccccccc}\text { Observations } & 1,440 & 1,447 & 794 & 1,440 & 1,447 & 794 \\ \text { Adjusted R-squared } & 0.452 & 0.454 & 0.502 & 0.382 & 0.380 & 0.505\end{array}$

Robust standard errors in parentheses. ${ }^{* *} \mathrm{p}<0.01,{ }^{* *} \mathrm{p}<0.05,{ }^{*} \mathrm{p}<0.1$.

Table A4. Capital flows and trade for developing countries.

\begin{tabular}{|c|c|c|c|c|c|c|}
\hline VARIABLES & $\begin{array}{c}\text { Chinn-Ito } \\
\text { index }\end{array}$ & $\begin{array}{c}\text { Chinn-Ito } \\
\text { index }\end{array}$ & $\begin{array}{c}\text { Chinn-Ito } \\
\text { index }\end{array}$ & FDI flows & FDI flows & FDI flows \\
\hline \multirow[t]{2}{*}{ FINDEV1 } & 0.533 & & & 2.479 & & \\
\hline & $(0.360)$ & & & $(2.144)$ & & \\
\hline FINDEV $1 \times$ TLIB & -0.385 & & & -0.916 & & \\
\hline
\end{tabular}




\section{Continued}

\begin{tabular}{|c|c|c|c|c|c|c|}
\hline & $(0.356)$ & & & $(1.886)$ & & \\
\hline \multirow[t]{2}{*}{ FINDEV2 } & & 0.414 & & & 1.283 & \\
\hline & & $(0.331)$ & & & (1.598) & \\
\hline \multirow[t]{2}{*}{ FINDEV $2 \times$ TLIB } & & $-0.588^{\star}$ & & & -0.398 & \\
\hline & & $(0.302)$ & & & $(1.422)$ & \\
\hline \multirow[t]{2}{*}{ FINDEV3 } & & & 0.264 & & & $3.041^{* * *}$ \\
\hline & & & $(0.382)$ & & & $(1.075)$ \\
\hline \multirow[t]{2}{*}{ FINDEV $3 \times$ TLIB } & & & -0.407 & & & -1.179 \\
\hline & & & $(0.337)$ & & & $(0.947)$ \\
\hline \multirow[t]{2}{*}{ TLIB } & $0.704^{* * *}$ & $0.756^{* * *}$ & $0.725^{\star * *}$ & $0.712^{*}$ & 0.587 & 0.327 \\
\hline & $(0.138)$ & $(0.139)$ & $(0.153)$ & $(0.424)$ & $(0.384)$ & $(0.249)$ \\
\hline \multirow[t]{2}{*}{ Corrupt } & $0.410^{\star * *}$ & $0.091^{* *}$ & $-0.425^{* * *}$ & $0.384^{* * *}$ & -0.175 & $-1.117^{\star * *}$ \\
\hline & $(0.060)$ & $(0.038)$ & $(0.065)$ & $(0.078)$ & $(0.110)$ & $(0.202)$ \\
\hline \multirow[t]{3}{*}{ Rule law } & $-0.613^{* * *}$ & $-0.129^{\star *}$ & $-0.555^{\star * *}$ & $0.724^{*}$ & $1.587^{* * *}$ & $2.351^{* * *}$ \\
\hline & $(0.080)$ & $(0.060)$ & $(0.063)$ & $(0.373)$ & $(0.420)$ & $(0.447)$ \\
\hline & \multicolumn{6}{|c|}{ Controls: country, year fixed effects, gdp } \\
\hline Observations & 1417 & 1424 & 789 & 1395 & 1402 & 772 \\
\hline Adjusted R-squared & 0.691 & 0.692 & 0.703 & 0.568 & 0.567 & 0.686 \\
\hline
\end{tabular}

Robust standard errors in parentheses. ${ }^{* *} \mathrm{p}<0.01,{ }^{* *} \mathrm{p}<0.05,{ }^{*} \mathrm{p}<0.1$.

Table A5. Country list.

\begin{tabular}{ccc}
\hline Country list & & Norway \\
Albania & Greece & Oman \\
Algeria & Guatemala & Pakistan \\
Angola & Guinea & Panama \\
Argentina & Guinea-Bissau & Paraguay \\
Armenia & Guyana & Peru \\
Australia & Haiti & Philippines \\
Austria & Honduras & Poland \\
Azerbaijan & Hungary & Portugal \\
Bangladesh & Iceland & Romania \\
Barbados & India & Rwanda \\
Belgium & Indonesia & Saudi Arabia \\
Belize & Iraq & Senegal \\
Benin & Ireland & Seychelles \\
Botswana & Israel & Sierra Leone \\
Brazil & Italy & Singapore \\
Bulgaria & Jamaica & Slovenia \\
Burkina Faso & Japan & \\
\hline & &
\end{tabular}




\section{Continued}

\begin{tabular}{|c|c|c|}
\hline Burundi & Jordan & Somalia \\
\hline Cameroon & Kenya & South Africa \\
\hline Canada & Kuwait & Spain \\
\hline Cape Verde & Latvia & Sri Lanka \\
\hline Central African Republic & Lesotho & Sudan \\
\hline Chad & Liberia & Swaziland \\
\hline Chile & Lithuania & Sweden \\
\hline China & Madagascar & Switzerland \\
\hline Colombia & Malawi & Syrian Arab Republic \\
\hline Congo, Rep. & Malaysia & Thailand \\
\hline Costa Rica & Maldives & Togo \\
\hline Croatia & Mali & Trinidad and Tobago \\
\hline Cyprus & Malta & Tunisia \\
\hline Czech Republic & Mauritania & Turkey \\
\hline Denmark & Mauritius & Uganda \\
\hline Dominican Republic & Mexico & Ukraine \\
\hline Ecuador & Moldova & United Kingdom \\
\hline El Salvador & Mongolia & United States \\
\hline Estonia & Morocco & Uruguay \\
\hline Ethiopia & Mozambique & Venezuela, RB \\
\hline Fiji & Myanmar & Yemen, Rep. \\
\hline Finland & Namibia & Zambia \\
\hline France & Nepal & Zimbabwe \\
\hline Gabon & Netherlands & \\
\hline Gambia, The & New Zealand & \\
\hline Georgia & Nicaragua & \\
\hline Germany & Niger & \\
\hline Ghana & Nigeria & \\
\hline
\end{tabular}

